\title{
Gemmiger formicilis, n.gen., n.sp., an Anaerobic Budding Bacterium from Intestines
}

\author{
JENNIFER GOSSLING ${ }^{1}$ aND W. E. C. MOORE \\ Department of Microbiology, West Virginia University Medical Center, Morgantown, West Virginia 26506 and \\ Anaerobe Laboratory, Virginia Polytechnic Institute and State University, Blacksburg, Virginia 24061
}

A species of strictly anaerobic, carbohydrate-fermenting, formic- and butyric acid-producing, gram-negative to gram-variable bacteria is described on the basis of 35 isolates from human feces and one isolate from chicken cecal contents. Members of this species produce morphological forms with the appearance of buds. This species cannot be assigned to any known genus, and therefore a new genus, Gemmiger (L. n. gemma a bud; L. v. gero to bear; M. L. masc. n. gemmiger bud bearer), is proposed with G. formicilis n.sp. (M. L. adj. formicilis pertaining to formic acid) as the type species. The type strain of this species is Virginia Polytechnic Institute strain X2-56 ( = ATCC 27749).

This report describes 35 bacterial isolates of a species that appears to be common in the large intestines of man and chickens. Strains of this species, conforming to the description below, occurred at $8.32( \pm 1.8$ standard deviation) $\times$ $10 \%$ (dry weight) of feces of 20 clinically healthy Japanese-Hawaiians and accounted for $1.75 \%$ ( \pm 0.39 standard deviation) of the cultivable fecal bacterial flora of this group of people (9). In other studies, bacteria with similar morphology were a major component in the cecal flora of chicks 2.0 to 6.5 weeks old (1). These morphological forms accounted for a mean of $1 \%$ of all bacteria observed microscopically in smears from 47 fecal specimens from North Americans (J. Gossling, Ph.D. dissertation, West Virginia University, Morgantown, 1973). Although bacteria with this morphology may have included a number of metabolic types, representative isolates from British chickens and North American humans were characterized, and they belong to the species described below.

\section{MATERIALS AND METHODS}

Isolates were obtained from feces of clinically healthy humans and the cecal contents of a chicken using one or another of the strictly anaerobic procedures described elsewhere $(1,3,4)$. In series $I, 35$ isolates from 35 humans were characterized (at Virginia Polytechnic Institute and State University [VPI \& SU]) using the procedures of Holdeman and Moore (4). In series II, eight isolates (two from series I and others from four humans and a chicken) were characterized (at West Virginia University Medical Center [WVUMC]) using tubes of prereduced basal medium containing yeast extract $(0.5 \%)$, salts solution (4) $(50 \%)$, and cysteine $(0.05 \%)$ under $50 \% \mathrm{CO}_{2}$ in nitro-

' Present address: 6 Cheyhan Mount, Eaton, Norwich, NOR 98D, England. gen. Carbohydrate $(0.2 \%)$ was added to this medium before autoclaving or, for the determination of fermentation products, $0.5 \%$ of filter-sterilized glucose was added after autoclaving. Other tests in series II followed the methods of Holdeman and Moore (4).

A representative strain of series II (Gossling L-61) was examined by electron microscopy. For scanning electron microscopy, late-growth-phase cells were prepared by the method of Klainer and Betsch (8) and examined in a Kent-Cambridge $\$ 410$ scanning electron microscope. Sections for examination by transmission electron microscopy were prepared by the method of Kingsbury and Voelz (6) (except that for some preparations $0.1 \mathrm{M}$ buffer was used to minimize apparent cytoplasmic shrinkage) and examined in an RCA-EMU-3G transmission electron microscope.

\section{RESULTS}

Morphology. By light microscopy, the organisms appeared as pairs or chains of spherical or tear-drop-shaped cells 0.3 to $1.0 \mu \mathrm{m}$ in diameter (Fig. 1-3, 7-8). The pairs frequently consisted of one large and one small body, resembling a budding yeast. In chains of up to eight or 10 bodies, there were often two small bodies between two larger ones. Single cells and elongated cells were seen occasionally. Cells from 8 to 16 -h-old cultures often stained weakly gram positive; older cultures were usually gram negative. All isolates were nonmotile. No spores were detected visually, and no culture survived at $80 \mathrm{C}$ for $10 \mathrm{~min}$.

Electron microscopy showed cells with one large end and a small end which had the appearance of a bud (Fig. 4,5). These cells were frequently in pairs with the two small ends adjacent, suggesting that second-generation cells were formed between the original mother and daughter cells. Sections showed a typical 


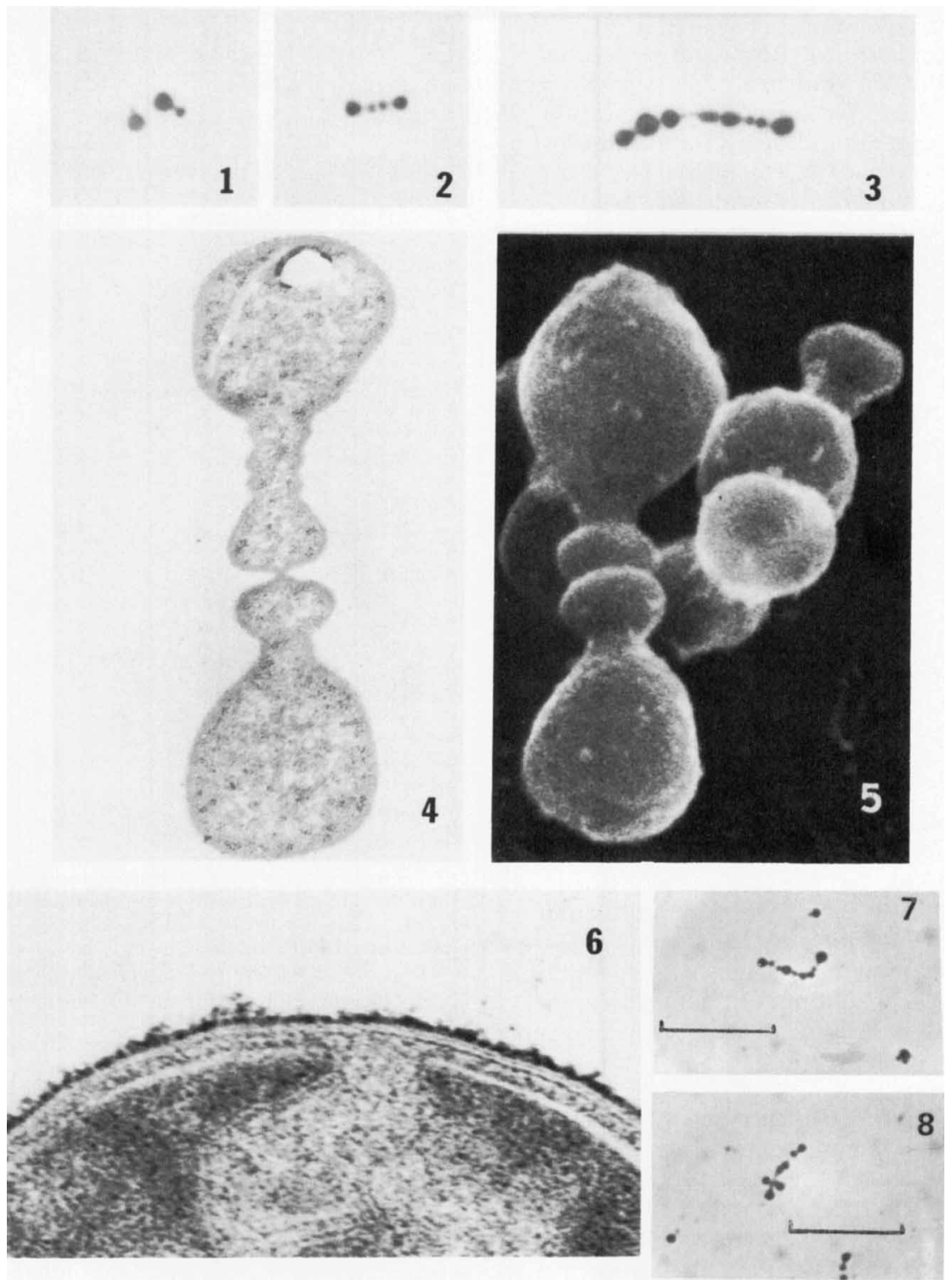

Fig. 1-3. Phase photomicrographs of G. formicilis strain Gossling L-61. $\times 2,500$.

Fig. 4. Electron micrograph of a longitudinal section of a pair of cells of G. formicilis strain Gossling L-61 which have apparently just completed division. (Harvested and fixed in $0.1 M$ buffer.) $\times 24,200$.

Fig. 5. Scanning electron micrograph of G. formicilis strain Gossling L-61. $\times 23,400$.

FIG. 6. Electron micrograph of section of G. formicilis strain Gossling L-61 to show cell wall structure. (Harvested and fixed in $0.2 \mathrm{M}$ buffer.) $\times 87,700$.

FIG. 7. Light micrograph of G. formicilis strain VPI X2-56 (24-h-old culture in peptone-yeast extract). Bar, 10 $\mu m$.

FIG. 8. Light micrograph of $G$. formicilis strain VPI X2-56 (24-h-old culture in peptone-yeast extractglucose). Bar, $10 \mu \mathrm{m}$.

procaryotic structure (Fig. 4). No cross walls were seen. It appeared that the cells separated by constriction between the two second-generation buds, giving rise to two equal cells with constrictions already formed. Sections of the cell wall showed many layers characteristic of gram-negative bacteria (2); the cell membrane appeared to adhere tightly to the walls, and a 
dense outer layer was present (Fig. 6). There were no flagella or other external structures.

Conditions for culture. All isolates were strict anaerobes. We were able to maintain all isolates in anaerobic tube cultures and most of them under glove box conditions on media containing palladium chloride and cysteine, if the freshly prepared media were placed quickly in the glove box and stored for $24 \mathrm{~h}$ under hydrogen before use. There was no growth on agar plates prepared from prereduced rumen fluid-glucose-cellobiose agar that had been exposed to air long enough to harden and be inoculated before being placed in GasPak (BBL) jars. These observations indicate that the species has a relatively high sensitivity to oxidized medium components.

Unidentified factors present in rumen fluid or yeast extract were required for growth. About one-half of the isolates required Tween 80 for optimal growth and fermentation.

Cultural and biochemical characteristics. Broth cultures with fermentable carbohydrate were turbid, but during incubation cells settled rapidly to form a sediment that often appeared ropy when swirled. Cell production was greatest at 37 to $45 \mathrm{C}$ for most strains. A few strains grew equally well at $30 \mathrm{C}$. Little or no growth was produced in the basal medium without carbohydrate. Colonies on the surface of agar streak tubes were 1 to $2 \mathrm{~mm}$ in diameter, circular, entire, and low convex. On clear media, they were transparent to translucent; on blood media, they were glistening, white, and opaque. On anaerobic chopped meat agar slants, cultures produced a thin spreading film. All cultures had a butyric odor.

The average concentrations (in $\mathrm{meq} / 100 \mathrm{ml}$ of culture) of acids from 35 strains in peptone-yeast extract-1\% glucose (4) cultures were: acetic, 0.3 ; formic, 1.4 ; butyric, 0.8 ; pyruvic, 0.5 ; and lactic, 0.8. Formic acid and butyric acid were always produced. Small amounts of acetic, pyruvic, and lactic, and traces of succinic and malonic acids were sometimes present. Little or no gas was produced and little or no hydrogen was detected (9) in head gas of fermented carbohydrate cultures. Glucose was fermented by all isolates. However, with some strains, fermentation was dependent upon the presence of Tween $80(0.01$ to $0.1 \%)$. Terminal $\mathrm{pH}$ in peptone-yeast extract-glucose broth (4) cultures was 5.1 to 5.4. Many other carbohydrates were used by some isolates (Table 1). Adonitol, dulcitol, erythritol, glycerol, inositol, mannitol, melezitose, raffinose, rhamnose, ribose, sorbitol, sorbose, and lactate were not fermented. The 35 isolates tested produced acetate, butyr-
TABLE 1. Variable cultural reactions of Gem miger formicilis

\begin{tabular}{|c|c|c|c|}
\hline \multirow[b]{2}{*}{ Substrate } & \multicolumn{2}{|c|}{$\begin{array}{l}\text { Reaction, series I } \\
\quad(\text { VPI \& SU) }\end{array}$} & \multirow{2}{*}{$\begin{array}{c}\text { Growth, } \\
\text { series II } \\
\text { (WVUMC) }^{b}\end{array}$} \\
\hline & $\begin{array}{c}35 \text { stains } \\
(2-5 \text { runs } \\
\text { each })\end{array}$ & $\begin{array}{c}\text { ATCC } \\
27749 \\
\text { (4-6 runs) }\end{array}$ & \\
\hline Amygdalin & $-w$ & $-w$ & 0 \\
\hline Arabinose & $-a$ & $-n$ & 0 \\
\hline Cellobiose & a- & a- & 6 \\
\hline Dextrin & $-a$ & - & 0 \\
\hline Esculin (pH) & $-a$ & w. & 1 \\
\hline Fructose & a- & $v$ & \\
\hline Galactose & a- & $-a$ & 7 \\
\hline Glycogen & $-\mathbf{a}$ & $-n$ & 4 \\
\hline Inulin & $-\mathbf{a}$ & $v$ & 1 \\
\hline Lactose & a- & aw & 7 \\
\hline Maltose & a- & $\mathbf{v}$ & \\
\hline Mannose & $-a$ & w- & 6 \\
\hline Melibiose & $-a$ & $-a$ & 4 \\
\hline Salicin & $-a$ & $-n$ & 1 \\
\hline Starch & $\mathrm{v}$ & $-w$ & 4 \\
\hline Starch hydrolyzed & $\mathbf{v}$ & - & \\
\hline Sucrose & $-\mathbf{a}$ & w. & 0 \\
\hline Trehalose & $-\mathbf{a}$ & - & 1 \\
\hline Xylose & $\mathbf{v}$ & $-\mathbf{n}$ & 4 \\
\hline Gelatin hydrolyzed & $-w$ & - & \\
\hline Milk & $c-$ & $\mathrm{c}$ & \\
\hline
\end{tabular}

a -, Negative result; $\mathrm{w}$, weak reaction (final $\mathrm{pH}, 5.5$ to 6.0 ), gelatin incomplete hydrolysis; a, acid produced (final $\mathrm{pH}$ below 5.5); v, variable result ( 40 to $60 \%$ of tests positive); $n$, no growth detected; c, curd (reaction is usually late). Where two results are listed, the first result occurred in more than $60 \%$ of the strains. Acid production is usually dependent on Tween 80 or rumen fluid for stimulation of growth. No individual strain had the less usual result (the second reaction listed) for every substrate examined.

${ }^{b}$ Results show number positive of eight tested. Growth was determined turbidimetrically. A 6 - to 100 -fold increase in optical density with increase in the concentration of butyric acid represented a positive result.

ate, and usually formate from prereduced peptone-yeast extract-pyruvate. None of the isolates produced indole, catalase, lecithinase, lipase, acetylmethylcarbinol, hydrogen sulfide, or urease. Ammonia was detected in some cultures but was not produced from arginine. Nitrate was not reduced; hippurate was not hydrolyzed. Esculin was hydrolyzed. Neutral red was reduced in fructose medium. Gelatin was partially liquefied by some strains; that is, chilled gelatin cultures melted at room temperature in about $30 \mathrm{~min}$, whereas uninoculated control tubes remained solid for more than $1 \mathrm{~h}$. Casein and meat were not digested.

$\mathbf{G}+\mathbf{C}$ ratio. The deoxyribonucleic acid of the type strain, as determined by J. L. Johnson using $T_{m}(7)$, contained $59 \mathrm{~mol} \%$ guanine plus cytosine $(\mathrm{G}+\mathrm{C})$. 
Despite considerable variation in the kinds of carbohydrates fermented, the isolates described here appear to fall into a single group and are assigned to a single new species. The variation in the kinds of carbohydrate fermented appears to be the result primarily of the amount of growth in individual cultures, which is affected by the age and size of inoculum and, in some cases, by the presence of Tween 80 and/or rumen fluid in the medium (Table 2).

\section{DISCUSSION}

This species does not have characteristics that permit its inclusion in any previously described genus. The requirement for fermentable carbohydrate is characteristic of organisms in the genus Ruminococcus. However, ruminococci do not produce butyric acid and are gram positive. The gram-negative anaerobic cocci that produce butyric acid were placed in the genus Acidaminococcus (10). However, that genus was restricted to organisms that do not require fermentable carbohydrate and that obtain their energy primarily from peptone or amino acids. Bacteria in the genus Veillonella produce propionic acid as a major product of energy metabolism. The genus Megasphaera was limited to include only those organisms with the morphology and fermentation pathway of $M$. elsdenii (11), which the presently described species does not resemble. Bodies of unequal size are frequently seen (although to a much lesser extent than with this species) in strains of Peptostreptococcus productus, Streptococcus constellatus, and Peptococcus magnus, but these are all species of frankly gram-positive organisms whose metabolic characteristics are significantly different from those of the species described here. The method of cell division which is thought to occur in the presently described species has been observed in two types of freshwater bacteria $(13,15)$. However,

TABLE 2. Cultural reactions of the type strain VPI X2-56 in those substrates known to give variable reactions within the species Gemmiger formicilis

\begin{tabular}{|c|c|c|c|c|c|c|c|c|c|c|c|c|}
\hline \multirow{3}{*}{ Substrate } & \multicolumn{12}{|c|}{ Test } \\
\hline & \multicolumn{2}{|c|}{$\begin{array}{c}8-11-72 \\
(\mathrm{E}, \mathrm{RF})^{a}\end{array}$} & \multicolumn{2}{|c|}{$\begin{array}{l}8-15-73 \\
(\mathrm{E}, \mathrm{RF})\end{array}$} & \multicolumn{2}{|c|}{$\begin{array}{c}1-10-74 \\
(\mathrm{CM}, \text { Tween })\end{array}$} & \multicolumn{2}{|c|}{$\begin{array}{l}3-26-74 \\
(E, R F)\end{array}$} & \multicolumn{2}{|c|}{$\begin{array}{c}\text { 3-26-74 } \\
\text { (E, Tween) }\end{array}$} & \multicolumn{2}{|c|}{$\begin{array}{c}3-26-74 \\
(\mathrm{E}, \text { none })\end{array}$} \\
\hline & Growth ${ }^{b}$ & $\begin{array}{c}\text { Reac- } \\
\text { tion }\end{array}$ & Growth & $\begin{array}{l}\text { Reac- } \\
\text { tion }\end{array}$ & Growth & $\begin{array}{c}\text { Reac- } \\
\text { tion }\end{array}$ & Growth & $\begin{array}{l}\text { Reac- } \\
\text { tion }\end{array}$ & Growth & $\begin{array}{l}\text { Reac- } \\
\text { tion }\end{array}$ & Growth & $\begin{array}{c}\text { Reac- } \\
\text { tion }\end{array}$ \\
\hline $\begin{array}{l}\text { Amygdalin } \\
\text { Arabinose } \\
\text { Cellobiose } \\
\text { Dextrin }\end{array}$ & $\begin{array}{l}++ \\
++ \\
++++ \\
\text { NT }\end{array}$ & $\begin{array}{l}-^{c} \\
- \\
\mathrm{a} \\
\mathrm{NT}\end{array}$ & $\begin{array}{l}++ \\
++ \\
++++ \\
+\end{array}$ & $\begin{array}{l}\mathbf{w} \\
- \\
\mathbf{a} \\
-\end{array}$ & $\begin{array}{l}+ \\
- \\
++++ \\
\text { NT }\end{array}$ & $\begin{array}{l}- \\
\text { n } \\
\text { a } \\
\text { NT }\end{array}$ & $\begin{array}{l}++ \\
++ \\
++t \\
+\end{array}$ & $\begin{array}{l}- \\
- \\
- \\
-\end{array}$ & $\begin{array}{l}++ \\
++ \\
+ \\
+\end{array}$ & $\begin{array}{l}\mathbf{w} \\
- \\
- \\
-\end{array}$ & $\begin{array}{l}++ \\
++ \\
++ \\
+\end{array}$ & $\begin{array}{l}- \\
- \\
- \\
-\end{array}$ \\
\hline $\begin{array}{l}\text { Esculin (pH) } \\
\text { Fructose } \\
\text { Galactose } \\
\text { Glycogen }\end{array}$ & $\begin{array}{l}++ \\
++ \\
\text { NT } \\
-\end{array}$ & $\begin{array}{l}\text { w } \\
\text { w } \\
\text { NT } \\
\text { n }\end{array}$ & $\begin{array}{l}++ \\
++ \\
+++ \\
-\end{array}$ & $\begin{array}{l}w \\
a \\
a \\
n\end{array}$ & $\begin{array}{l}++ \\
+ \\
\text { NT } \\
+\end{array}$ & $\begin{array}{l}\text { w } \\
- \\
\text { NT } \\
-\end{array}$ & $\begin{array}{l}++ \\
+++ \\
+++ \\
+\end{array}$ & $\begin{array}{l}- \\
- \\
-\end{array}$ & $\begin{array}{l}++ \\
+++ \\
++ \\
+\end{array}$ & $\begin{array}{l}- \\
\mathbf{w} \\
\mathbf{w} \\
-\end{array}$ & $\begin{array}{l}+ \\
++ \\
++ \\
+\end{array}$ & $\begin{array}{l}- \\
- \\
- \\
-\end{array}$ \\
\hline $\begin{array}{l}\text { Inulin } \\
\text { Lactose } \\
\text { Maltose } \\
\text { Mannose }\end{array}$ & $\begin{array}{l}\text { NT } \\
+++ \\
- \\
++\end{array}$ & $\begin{array}{l}\text { NT } \\
\mathbf{w} \\
\text { n } \\
\text { w }\end{array}$ & $\begin{array}{l}+++ \\
++++ \\
++ \\
++\end{array}$ & $\begin{array}{l}w \\
a \\
w \\
w\end{array}$ & $\begin{array}{l}\text { NT } \\
++++ \\
++++ \\
+\end{array}$ & $\begin{array}{l}\text { NT } \\
a \\
a \\
w\end{array}$ & $\begin{array}{l}++ \\
+++ \\
+++ \\
+++\end{array}$ & $\begin{array}{l}- \\
a \\
a \\
-\end{array}$ & $\begin{array}{l}++ \\
++ \\
++ \\
+\end{array}$ & $\begin{array}{l}\mathbf{a} \\
\mathbf{a} \\
\mathbf{w} \\
-\end{array}$ & $\begin{array}{l}+ \\
++++ \\
++ \\
+\end{array}$ & $\begin{array}{l}- \\
\mathbf{a} \\
-\end{array}$ \\
\hline $\begin{array}{l}\text { Melibiose } \\
\text { Salicin } \\
\text { Starch }(\mathrm{pH}) \\
\text { Starch hydrolyzed }\end{array}$ & $\begin{array}{l}+++ \\
- \\
++ \\
++\end{array}$ & $\begin{array}{l}- \\
\mathbf{n} \\
\mathbf{w} \\
-\end{array}$ & $\begin{array}{l}+ \\
++ \\
++ \\
++\end{array}$ & $\begin{array}{l}- \\
- \\
- \\
-\end{array}$ & $\begin{array}{l}+ \\
+ \\
++ \\
++\end{array}$ & $\begin{array}{l}- \\
- \\
\mathbf{w} \\
-\end{array}$ & $\begin{array}{l}++ \\
++ \\
+++ \\
+++\end{array}$ & $\begin{array}{l}a \\
- \\
- \\
-\end{array}$ & $\begin{array}{l}++ \\
++ \\
+ \\
+\end{array}$ & $\begin{array}{l}a \\
- \\
- \\
-\end{array}$ & $\begin{array}{l}++ \\
++ \\
++ \\
++\end{array}$ & $\begin{array}{l}- \\
- \\
- \\
-\end{array}$ \\
\hline $\begin{array}{l}\text { Sucrose } \\
\text { Trehalose } \\
\text { Xylose }\end{array}$ & $\begin{array}{l}+++ \\
++ \\
+++\end{array}$ & $\begin{array}{l}\mathbf{w} \\
- \\
-\end{array}$ & $\begin{array}{l}++ \\
+ \\
++\end{array}$ & $\begin{array}{l}\mathbf{w} \\
- \\
-\end{array}$ & $\begin{array}{l}+++ \\
+ \\
-\end{array}$ & $\begin{array}{l}\mathbf{w} \\
- \\
\mathrm{n}\end{array}$ & $\begin{array}{l}++ \\
++ \\
++\end{array}$ & $\begin{array}{l}- \\
- \\
-\end{array}$ & $\begin{array}{l}+ \\
++ \\
++\end{array}$ & $\begin{array}{l}- \\
- \\
-\end{array}$ & $\begin{array}{l}++ \\
+ \\
++\end{array}$ & $\begin{array}{l}- \\
- \\
-\end{array}$ \\
\hline Gelatin hydrolyzed & $\begin{array}{l}++ \\
\mathrm{NE}\end{array}$ & - & $\begin{array}{l}\text { NT } \\
\text { NE }\end{array}$ & NT & $\begin{array}{l}+++ \\
\mathrm{NE}\end{array}$ & - & $\begin{array}{l}++ \\
\mathrm{NE}\end{array}$ & - & $\begin{array}{l}++ \\
\text { NE }\end{array}$ & - & $\begin{array}{l}++ \\
\mathrm{NE}\end{array}$ & - \\
\hline
\end{tabular}

a (Growth medium for inoculum culture, supplement added to test media): E, "E" medium (4); CM, chopped meat medium (4) $\mathrm{RF}$, rumen fluid added to a final concentration of $10 \%$; Tween, Tween 80 added to a final concentration of $0.01 \%$.

- Amount of growth estimated on a - to ++++ scale. NE (milk), No estimate made.

$c_{-}$, Negative reaction or, for carbohydrates, $\mathrm{pH}=>6.0 ; \mathrm{w}, \mathrm{pH} 5.5$ to $6.0 ; \mathrm{a}, \mathrm{pH}<5.5 ; \mathrm{c}$, curd; $\mathrm{n}$, no result recorded because of no growth; NT, not tested. 
one of these, Hyphomicrobium, is an obligate aerobe, although anaerobic growth can be obtained in the presence of nitrate, and the other, Ancalomicrobium, is normally aerobic although it can ferment sugar. This latter genus is restricted to bacteria with two to eight prosthecae (13), and the $\mathrm{G}+\mathrm{C}$ ratio of the type species is $71 \mathrm{~mol} \%$ (14) as opposed to $59 \mathrm{~mol} \%$ for the species described here. Physiologically, the present isolates resemble most closely organisms of the genus Coprococcus (5). However, species in that genus are gram positive, have 41 to $42 \mathrm{~mol} \% \mathrm{G}+\mathrm{C}$ in the deoxyribonucleic acid, and do not produce buds or prosthecae.

In the absence of existing genera with definitions broad enough to include this species, we feel obliged to place it in a new genus. This genus is to be restricted to anaerobic, gram-negative to gram-variable bacteria which use carbohydrate as their major energy source and show morphological characteristics similar to those of this species.

The family Veillonellaceae, which includes the genera of gram-negative anaerobic cocci, might be expanded to include this new genus (among the autotrophic bacteria, budding and fission bacteria are included in the same family), but presently the family only includes spherical bacteria which divide to give the basic diplococcal arrangement observed in Megasphaera and Acidaminococcus (10-12). Therefore, pending further study, this new genus is not assigned to a family.

Gemmiger n.gen. (Gem'mi.ger L. n. gemma a bud; L. v. gero to bear; M. L. masc. n. Gemmiger bud bearer). Gram-negative to gram-variable bacteria that apparently reproduce by constriction, giving the appearance of buds. Grow anaerobically with carbohydrate as the only or major energy source. Produce formic, butyric, or other acid products. The type species is $G$. formicilis.

Gemmiger formicilis n.sp. (for.mi'ci.lis, M. L. adj. formicilis pertaining to formic acid). Strictly anaerobic, mesophilic, fermentative, gram-negative to gram-variable bacteria which require glucose, fructose, maltose, or some other fermentable carbohydrate for growth. The fermentation products include formic and $n$ butyric acids, often with small amounts of acetic, lactic, succinic, malonic, and pyruvic acids. The terminal $\mathrm{pH}$ in weakly buffered media is 5.0 to 5.4. Cultures do not ferment lactate or amino acids, do not hydrolyze proteins or lipids, and do not reduce nitrates or produce catalase. The cells have a characteristic hourglass shape with one end usually smaller than the other. Typical dimensions are: larger end, 0.6 to $1.2 \mu \mathrm{m}$ in diameter; smaller end, 0.2 to $0.8 \mu \mathrm{m}$ in diameter; overall length, 1.0 to 2.3 $\mu \mathrm{m}$. Pairs of cells are attached by the smaller ends. Chains are commonly seen. The cells are nonsporeforming, nonmotile, and bear no flagella or other external structure. The $\mathrm{G}+\mathrm{C}$ ratio is $59 \mathrm{~mol} \%$. The species is common in the feces of humans and the cecum of chickens. The type strain is VPI X2-56 (= ATCC 27749); it was isolated from the feces of a clinically healthy North American woman.

Characterization. The species is readily distinguished from other strictly anaerobic gram-negative intestinal bacteria by its morphology as seen under the light microscope (Fig. $1-3)$, its requirement for carbohydrate, and its production of butyrate and formate in the absence of significant gas formation. Formic acid often was detected only from the particular carbohydrate cultures of a test series in which good growth and low $\mathrm{pH}$ were produced. Tween 80 or rumen fluid may be required for optimum growth and characteristic activity. The reactions cited in Table 1 and the text confirm its identity.

\section{ACKNOWLEDGMENTS}

We are grateful to John Johnson for determining the $\mathbf{G}+\mathrm{C}$ ratio, to T. O. MacAdoo for nomenclatural terminology, to Elizabeth P. Cato and Carolyn Salmon for aid in characterizing cultures, to Ella Barnes for helpful discussion and for providing the chicken isolate, and to Herbert Voelz, Steve Gonda, Phillip Allender, Susanna Jernigan, and Marion Rectenwald for assistance with electron microscopy.

The characterization of the series I isolates was supported by Public Health Service contract NO1-CP-33334 from the National Cancer Institute.

\section{REPRINT REQUESTS}

Address reprint requests to: Dr. W. E. C. Moore, Anaerobe Laboratory, Virginia Polytechnic Institute and State University, P.O. Box 49, Blacksburg, Va. 24061.

\section{LITERATURE CITED}

1. Barnes, E. M., G. C. Mead, D. A. Barnum, and E. G. Harry. 1972. The intestinal flora of the chicken in the period 2 to 6 weeks of age, with particular reference to the anaerobic bacteria. Br. Poult. Sci. 13:311-326.

2. Glauert, A. M., and M. J. Thornley. 1969. The topography of the bacterial cell wall. Annu. Rev. Microbiol. 23:159-198.

3. Gossling, J., and J. M. Slack. 1974. Predominant grampositive bacteria in human feces: numbers, variety, and persistence. Infect. Immun. 9:719-729.

4. Holdeman, L. V., and W. E. C. Moore (ed.). 1973. Anaerobe laboratory manual, 2nd ed. Virginia Poly technic Institute and State University, Blacksburg.

5. Holdeman, L. V., and W. E. C. Moore. 1974. A new genus, Coprococcus, twelve new species, and emended descriptions of four previously described species of bacteria from human feces. Int. J. Syst. Bacteriol. 24:260-277. 
6. Kingsbury, E. W., and H. Voelz. 1968. Structural organization of ribonucleoprotein in Escherichia coli. J. Bacteriol. 95:1478-1480.

7. Marmur, J., and P. Doty. 1962. Determination of the base composition of deoxyribonucleic acid from its thermal denaturation temperature. J. Mol. Biol. 5:109-118.

8. Klainer, A. S., and C. J. Betsch. 1970. Scanning beam electron microscopy of selected microorganisms. J. Infect. Dis. 121:339-343.

9. Moore, W. E. C., and L. V. Holdeman. 1974. Human fecal flora: the normal flora of 20 Japanese-Hawaiians. Appl. Microbiol. 27:961-979.

10. Rogosa, M. 1969. Acidaminococcus gen.n., Acidaminococcus fermentans sp.n., anaerobic gram-negative diplococci using amino acids as the sole energy source for growth. J. Bacteriol. 98:756-766.

11. Rogosa, M. 1971. Transfer of Peptostreptococcus elsdenii (Guiterrez et al.) to a new genus. Megasphaera $[M$. elsdenii (Guiterrez et al.) comb. nov.]. Int. J. Syst. Bacteriol. 21:187-189.

12. Rogosa, M. 1971. Transfer of Veillonella Prévot and Acidaminococcus Rogosa from Neisseriaceae to Veillonellaceae fam. nov. and the inclusion of Megasphaera Rogosa in Viellonellaceae. Int. J. Syst. Bacteriol. 21:231-233.

13. Staley, J. T. 1968. Prosthecomicrobium and Ancalomicrobium: new prosthecate freshwater bacte. ria. J. Bacteriol. 95:1921-1942.

14. Staley, J. T., and M. Mandel. 1973. Deoxyribonucleic acid base composition of Prosthecomicrobium and Ancalomicrobium strains. Int. J. Syst. Bacteriol. 23:271-273.

15. Whittenbury, R., and J. M. Nicoll. 1971. A new, mushroom shaped budding bacterium. J. Gen. Microbiol. 66:123-126. 